\title{
ANALISIS DAYA SAING SEKTOR INDUSTRI PRIORITAS INDONESIA DALAM MENGHADAPI PASAR ASEAN
}

\author{
Isventina $^{1}$, Nunung Nuryartono ${ }^{2}$, M. Parulian Hutagaol ${ }^{2}$ \\ ${ }^{1}$ Staf pada Kementerian Perdagangan dan Mahasiswa Magister Program Studi Ilmu \\ Ekonomi, FEM IPB \\ ${ }^{2}$ Staf Pengajar FEM IPB
}

Artikel diterima Maret 2015

Artikel disetujui untuk dipublikasikan Juli 2015

\begin{abstract}
This study aimed to analyze the factors that influence competitiveness of Indonesia's priority industrial sector in facing the ASEAN market by using Revealed Comparative Advantage (RCA) and panel data analysis. The study period was in 2001-2013 and variables are used, among others, the export price of products in the industry priorities, labor productivity, fixed capital and riil exchange rate. Based on the calculation of the level of competitiveness by using RCA, showed that the Indonesia's priority industrial sectors have strong competitive $(R C A>1)$ in the ASEAN market, except for the chemical industry and machinery and equipment industry. That is, Indonesia has a comparative advantage in most of the priority industrial sectors, so that it can be used to support the government's strategy to expand the national industrial market to the ASEAN region. While the results of the panel data analysis showed that the export price is the most influential factor for the competitiveness of priority industrial sectors in Indonesia. In this case, the export price is a reflection of the production cost. The high of production cost indicates that the purchase price of inputs by exporting companies is also high, so that the export price was high. Because the essence of competitiveness is relatively low cost, the high export prices showed a decreasing competitiveness. Other factors that affect are the real exchange rate and labor productivity. Rupiah depreciation can encourage the growth of exports, which in turn can improve competitiveness. Meanwhile, the development of human resources that make industrial policy was originally based on cheap labor and natural resources can be developed into a productivity-based industries are supported by qualified human resources as well as science and high technology. On the other hand, the addition of variable fixed capital does not affect the competitiveness of priority industrial sectors. This is because the impact of the increased competitiveness of the addition of fixed capital in a given year is not directly felt in the year, but will be felt in the next few years. Thus, the strategy can be formulated to improve the competitiveness of the priority industrial sectors, including developing the upstream industry and among industry based on natural resources and the control of exports of raw materials, develop human resources industry players in the Indonesia's priority industrial sectors with training and innovation activities, developing downstream industries as well as the increase in value-added products in the priority industrial sectors through product diversification and improve the pattern of cooperation with the manufacturers of other countries in the ASEAN region through the export promotion.
\end{abstract}

Keywords: ASEAN Integration, Manufacturing Industry, Competitiveness, Panel Data Analysis 


\section{PENDAHULUAN}

Globalisasi ekonomi merupakan suatu proses dimana semakin banyak negara yang terlibat langsung dalam kegiatan ekonomi global sehingga, hubungan suatu negara dengan negara lainnya menjadi semakin terbuka (Tambunan 2004). Hal ini telah meningkatkan hubungan saling ketergantungan ekonomi sekaligus persaingan antar negara. Liberalisasi perdagangan dunia ditandai dengan semakin cepatnya aliran barang dan jasa antar negara serta semakin berkembangnya sistem inovasi teknologi informasi, perdagangan, reformasi politik, transnasionalisasi sistem keuangan dan investasi. Indonesia mengikuti arus perdagangan bebas internasional dengan menandatangani General Agreement on Tariffs and Trade (GATT) yang menghasilkan pembentukan World Trade Organization (WTO) dan deklarasi Asia Pasific Economic Cooperation (APEC) tentang sistem perdagangan bebas dan investasi yang berlaku penuh pada tahun 2010 untuk negara maju dan tahun 2020 bagi negara berkembang.

Tidak kalah pentingnya, Indonesia bersama-sama negara-negara di kawasan ASEAN lainnya juga sepakat membentuk perdagangan bebas ASEAN, yaitu ASEAN Free Trade Area (AFTA). AFTA secara resmi diberlakukan pada tanggal 1 Januari 2003 pada negara ASEAN-6 (Indonesia, Philipina, Thailand, Singapura, Brunei dan Malaysia) dan negara ASEAN-4 (Vietnam mulai diberlakukan pada tahun 2006, Laos dan Myanmar pada tahun 2008, Kamboja pada tahun 2010). Dengan diberlakukannya AFTA ini, maka negara-negara anggota harus menurunkan pengenaan tarif impor intra ASEAN menjadi 5-0 persen bagi barang-barang yang dimasukakan ke dalam Daftar Inklusi (Inclusive List) dan telah memenuhi ketentuan tentang kandungan produk ASEAN. Pada akhirnya, keseluruhan tarif ini dihapuskan sama sekali (menjadi 0 persen) untuk negara ASEAN-6 pada tahun 2010 dan bagi negara ASEAN-4 pada tahun 2015, sehingga akan tercipta kawasan perdagangan regional Asia Tenggara yang benar-benar bebas bagi para anggota ASEAN.

Pembentukan AFTA mengukuhkan terbentuknya pasar tunggal ASEAN yang tujuannya adalah untuk menciptakan pasar yang terintegrasi antar negara anggota ASEAN dan sasarannya adalah meningkatkan daya saing ekonomi ASEAN sebagai product based dalam menghadapi persaingan di pasar dunia, sehingga kegiatan produksi dilakukan dengan memanfaatkan keunggulan masing-masing negara anggota. Dengan menghilangkan hambatan tarif inter-regional di kawasan ASEAN, daya saing negara-negara ASEAN diharapkan lebih kompetitif sehingga rasio volume perdagangan ASEAN maupun dunia semakin meningkat (Istifadah 2012).

Menjelang AEC-2015, persaingan di antara negara-negara ASEAN akan semakin ketat dalam memperebutkan peluang dalam pasar ASEAN. Jika tidak mampu bersaing, Indonesia sebagai negara terbesar di ASEAN dengan jumlah penduduk kurang lebih 250 juta jiwa berpotensi dibanjiri produk-produk dari negara ASEAN lainnya. Sebaliknya, bila industri nasional mampu bersaing dalam pasar ASEAN, maka akan memberikan manfaat bagi perekonomian Indonesia. Tantangan yang dihadapi oleh Indonesia dalam memanfaatkan pasar tunggal ASEAN adalah daya saing Indonesia yang masih relatif lebih rendah dibandingkan dengan negara-negara di ASEAN.

Hal ini dapat ditunjukkan dari data International Institute for Management Development/IMD (2014) yang menunjukkan bahwa peringkat daya saing industri Indonesia cenderung menempati peringkat paling bawah di antara beberapa negara ASEAN, seperti Singapura, 
Malaysia, Thailand dan Philipina. Bahkan Indonesia sempat menduduki posisi daya saing industri terendah di ASEAN, yaitu pada tahun 2007 dengan peringkat ke-54.
Sementara untuk negara Malaysia, Thailand dan Philipina memiliki daya saing industri yang relatif stabil (Gambar $1)$.

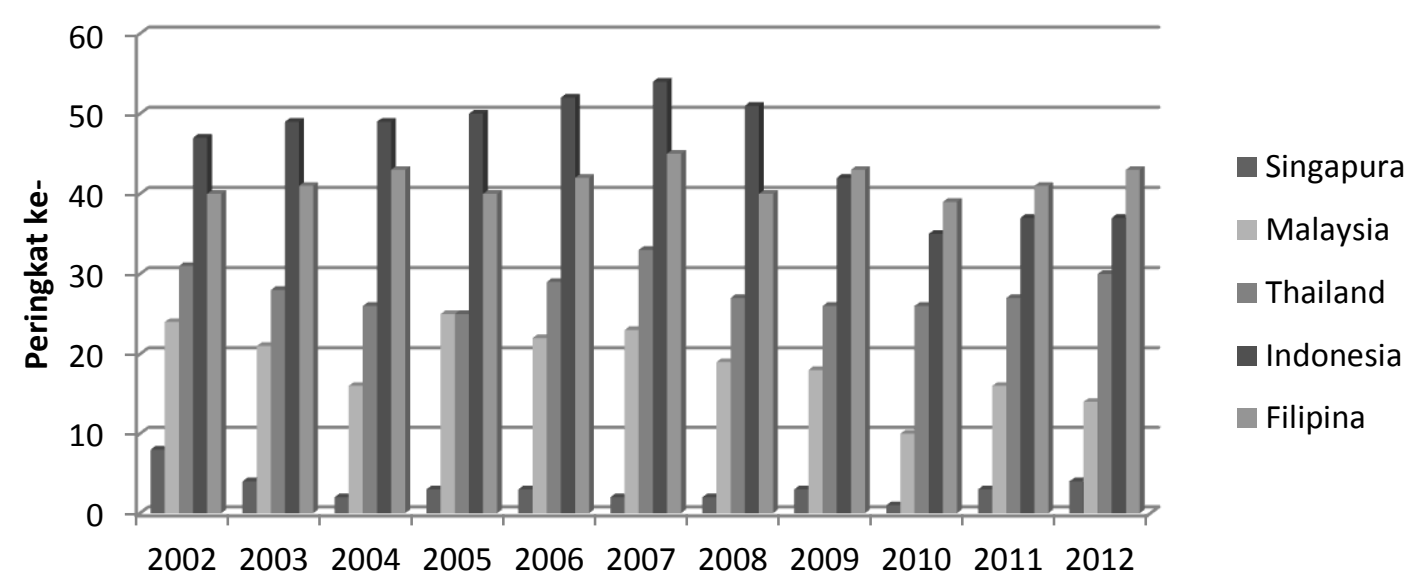

Sumber: IMD World Competitiveness 2014

Gambar 1 Peringkat daya saing industri manufaktur negara-negara ASEAN tahun 2002-2012

Sejumlah langkah peningkatan daya saing dilakukan oleh pemerintah Indonesia terhadap sektor-sektor yang dianggap strategis untuk diliberalisasikan menuju pasar tunggal ASEAN, dimana salah satunya adalah sektor industri manufaktur. Bagi Indonesia sendiri, sektor industri manufaktur merupakan salah satu sektor penting dalam perekonomian. Selain karena meningkatnya ekspor dan peranan sektor ini terhadap Produk Domestik Bruto (PDB) nasional, industri manufaktur juga merupakan industri padat karya yang menyerap banyak tenaga kerja. Dalam hal ini, Kementerian Perindustrian (Kemenperin) RI telah menyiapkan beberapa industri yang akan digenjot untuk siap menghadapi gempuran industri-industri asing, khususnya yang berasal dari kawasan ASEAN.

Dalam rangka menguasai pasar ASEAN, Kemenperin menyiapkan strategi ofensif melalui fokus pengembangan sembilan sektor industri prioritas, antara lain industri berbasis agro (CPO, kakao, dan karet), industri ikan dan produk olahannya, industri tekstil dan produk tekstil, industri alas kaki dan produk kulit, industri furniture, industri makanan dan minuman, industri pupuk dan petrokimia, industri mesin dan peralatannya, serta industri logam dasar besi dan baja. Industri-industri ini diprioritaskan untuk dikembangkan karena memiliki daya saing yang relatif lebih baik dibandingkan negara-negara ASEAN lainnya. Dari kesembilan sektor industri prioritas tersebut, yang termasuk ke dalam sub sektor industri manufaktur berdasarkan Klasifikasi Baku Lapangan Usaha Indonesia (KBLI) digit 2, yaitu industri tekstil dan produk tekstil, industri kulit dan barang dari kulit (alas kaki), industri furnitur, industri makanan dan minuman, industri kimia dan barang-barang dari bahan kimia, industri mesin dan peralatannya, serta industri logam dasar. Industri-industri tersebutlah yang akan dibahas lebih dalam pada penelitian ini. 
Terkait dengan sektor industri yang diunggulkan oleh pemerintah Indonesia karena dianggap dapat bersaing di pasar ASEAN, penetapan sektor industri prioritas teraebut dirasa perlu dianalisa kembali mengingat masih adanya beberapa kendala yang dihadapi oleh industri-industri prioritas tersebut yang dapat menghambat daya saingnya di pasar ASEAN. Kinerja sektor industri prioritas yang masih kurang baik membuat banyak kalangan pesimis akan kemampuan Indonesia untuk unggul, atau bahkan dapat bertahan di pasar ASEAN. Selain itu, penetapan sektor industri prioritas oleh pemerintah juga tidak disertai oleh indikator-indikator yang menentukan bahwa sektor industri prioritas tersebut memang memiliki daya saing. Kemampuan bersaing produk yang dihasilkan oleh sektor industri prioritas Indonesia perlu dipahami dengan melakukan komparasi terhadap produk sejenis yang dihasilkan oleh sektor industri prioritas di negara-negara ASEAN lainnya.

Berdasarkan latar belakang dan identifikasi yang telah diuraikan di atas, maka memberikan ruang bagi peneliti untuk mengkaji lebih lanjut terkait analisis daya saing sektor industri prioritas dalam menghadapi pasar ASEAN. Dengan demikian, tujuan yang ingin dicapai dari penelitian ini adalah menganalisis daya saing sektor industri prioritas Indonesia di pasar ASEAN serta faktor-faktor yang mempengaruhi daya saingnya guna merumuskan kebijakan atau strategi yang diharapkan dapat meningkatkan daya saing sektor industri prioritas Indonesia di pasar ASEAN.

Berkenaan dengan tujuan tersebut, ada beberapa tinjauan pustaka yang menjadi dasar dalam melakukan penelitian ini, di antaranya adalah mengenai konsep daya saing. Daya saing adalah suatu konsep mekanisme untuk mempertimbangkan sekelompok indikator luar negeri yang menekankan pada kinerja relatif antar negara. Daya saing tersebut dapat dipengaruhi secara bersamaan oleh banyak faktor, yang menurut sifatnya (endogen/bisa dikontrol dan eksogen/tidak bisa dikontrol) bisa dikelompokkan ke dalam dua kategori, yakni faktor-faktor di sisi permintaan dan faktor-faktor di sisi penawaran yang kemudian disebut sebagai faktor-faktor penentu daya saing di tingkat makro (Tambunan dan Sitepu 2012). Faktor-faktor di sisi permintaan bersifat eksogen bagi Indonesia, termasuk perubahan harga di pasar internasional untuk semua produk yang Indonesia ekspor. Sementara itu, faktor-faktor yang bersifat endogen bagi Indonesia adalah dari sisi penawaran yang meliputi sumber daya manusia (SDM), ketersediaan/ penguasaan teknologi, ketersediaan bahan baku bukan hanya dalam arti jumlah, tetapi juga kualitas dan harga, infrastruktur dan logistik dalam kuantitas dan kualitas, industri-industri pendukung, barang-barang modal dan perantara, energi, ketersediaan informasi, dan kebijakan khusus ekspor.

Yang membuat faktor-faktor di sisi penawaran semakin kompleks dari sudut pandang kebijakan pemerintah adalah bahwa masing-masing dari faktor-faktor tersebut mewakili sektor masing-masing, dan ini berarti berbagai kebijakan sektoral secara tidak langsung juga berpengaruh terhadap tingkat daya saing. Contohnya dalam hal kebijakan moneter, misalnya nilai tukar Rupiah yang terlalu tinggi membuat daya saing harga dari ekspor Indonesia menurun relatif dibandingkan harga dari produk yang sama buatan negara lain. Dengan harga yang lebih murah tersebut menyebabkan permintaan terhadap produk-produk ekspor Indonesia meningkat yang pada akhirnya dapat mendorong peningkatan daya saing.

Selain dibedakan menurut sifatnya seperti yang diuraikan di atas, faktor-faktor yang mempengaruhi tingkat daya saing juga dapat dibedakan menurut tingkatnya, 
yakni pada tingkat makro dan tingkat mikro (Tambunan dan Sitepu 2012). Di tingkat makro adalah yang telah dibahas di atas, yakni faktor-faktor di sisi permintaan dan sisi penawaran yang mempengaruhi daya saing nasional secara keseluruhan. Sedangkan di tingkat mikro adalah mengenai daya saing ekspor dari sebuah perusahaan secara individu. Tingkat daya saing sebuah perusahaan tercerminkan dari tingkat daya saing dari produk yang dihasilkan oleh perusahaan tersebut. Dalam gilirannya, daya saing dari perusahaan tersebut ditentukan oleh banyak faktor, tujuh diantaranya yang sangat penting adalah: keahlian atau tingkat pendidikan pekerja, keahlian pengusaha, ketersediaan modal, sistem organisasi dan manajemen yang baik, ketersediaan teknologi, ketersediaan informasi, dan ketersediaan input-input lainnya seperti energi dan bahan baku.

Sementara itu, menurut Sugiyanto (2004), dalam perspektif mikro, indikator daya saing suatu industri juga dapat dilihat dari tingkat harga relatif. Tingkat harga relatif yang semakin rendah, menunjukkan tingkat daya saing industri yang semakin tinggi. Harga relatif dapat juga dikatakan sebagai biaya yang dikeluarkan produsen selama proses produksi. Dalam hal ini biaya produksi berpengaruh terhadap harga ekspor karena harga yang dikeluarkan oleh produsen merupakan harga pembelian input perusahaan eksportir untuk menghasilkan produk-produk yang diekspor, sehingga juga menentukan harga ekspornya. Harga ekspor yang rendah karena rendahnya harga input akan mendorong peningkatan daya saing karena pada dasarnya esensi dari daya saing itu sendiri adalah biaya yang relatif rendah. Dengan kata lain, esensi peningkatan daya saing adalah penurunan biaya.

Di sisi lain, Porter (1990) juga menyatakan bahwa dalam persaingan global saat ini, suatu negara yang memiliki competitive advantage of nation dapat bersaing di pasar internasional bila memiliki empat faktor penentu dan dua faktor pendukung. Empat faktor utama yang menentukan daya saing suatu komoditi adalah kondisi faktor (factor condition), kondisi permintaan (demand condition), industri terkait dan industri pendukung yang kompetitif (related and supporting industry), serta kondisi struktur, persaingan dan strategi industri (firm strategy, structure, and rivalry). Dua faktor lainnya yang mempengaruhi interaksi antara keempat faktor tersebut, yaitu faktor kesempatan (chance event) dan faktor pemerintah (government).

Selanjutnya, pada bagian kedua dalam penelitian ini akan disajikan mengenai metode penelitian, kemudian bagian ketiga tentang hasil dan pembahasan dan bagian terakhir adalah simpulan dan saran serta daftar pustaka.

\section{METODE PENELITIAN}

Data yang digunakan dalam penelitian ini adalah data sekunder dari berbagai sumber, antara lain Kementerian Perdagangan (Kemendag), Badan Pusat Statistik (BPS), World Integrated Trade Solution (WITS), ASEAN Secretariat, Trademap serta Jurnal dan literatur-literatur yang berkaitan dengan penelitian ini. Data yang dikumpulkan tersebut merupakan data panel dengan time series tahunan yang dimulai dari tahun 2001 sampai dengan 2013 dan cross section berupa 8 (delapan) sub sektor industri manufaktur berdasarkan KBLI digit 2 yang merupakan bagian dari sektor industri prioritas Indonesia.

Penelitian ini menggunakan metode analisis deskriptif kualitatif dan kuantitatif. Daya saing industri prioritas Indonesia di pasar ASEAN secara komparatif dianalisis dengan menggunakan RCA. Nilai RCA ini kemudian digunakan sebagai variabel 
terikat dalam persamaan model panel guna mengetahui faktor-faktor yang mempengaruhi daya saing sektor industri prioritas Indonesia. Pada akhirnya, akan dirumuskan strategi atau kebijakan yang diharapkan dapat meningkatkan daya saing sektor industri prioritas Indonesia di pasar ASEAN.

\section{Revealed Comparative Advantage (RCA)}

Konsep ini pertama kali digunakan oleh Bela Balassa pada tahun 1965, dimana Balassa mencoba memisahkan batas demarkasi antara negara berdasarkan revealed comparative advantage pada sektor tertentu dengan negara yang tidak memilikinya. Pada penelitian ini, variabel yang diukur adalah kinerja ekspor produk dari sektor industri prioritas suatu negara di kawasan ASEAN terhadap total ekspor negara tersebut yang kemudian dibandingkan dengan pangsa nilai produk dari sektor industri prioritas dalam perdagangan di kawasan ASEAN. Jika pangsa ekspor produk dari sektor industri prioritas di dalam total ekspor produk dari suatu negara lebih besar dibandingkan pangsa pasar ekspor produk di dalam total ekspor komoditi ASEAN, diharapkan negara tersebut memiliki keunggulan komparatif dalam produksi dan ekspor produk dari sektor industri prioritas. Adapun rumusnya adalah sebagai berikut:

$\mathrm{RCA}=\frac{X i j / X i}{X w j / X w}=\frac{X i j / X w j}{X i / X w}$

dimana: $X=$ ekspor, $\mathrm{i}=$ negara tertentu, $\mathrm{j}=$ produk pada sektor industri prioritas, $\mathrm{w}=$ ASEAN.

\section{Analisis Data Panel}

Dalam penelitian ini, untuk menganalisis faktor-faktor yang mempengaruhi daya saing sektor industri prioritas Indonesia dilihat dari beberapa variabel, yaitu harga ekspor sektor industri prioritas, produktivitas tenaga kerja pada sektor industri prioritas, penambahan modal tetap pada sektor industri prioritas dan nilai tukar riil Rupiah terhadap Dollar. Penggunaan variabel-variabel independen tersebut selain disesuaikan dengan tujuan penelitian, juga disesuaikan dengan faktor-faktor penentu daya saing berdasarkan teori yang disampaikan oleh Porter (1990), Sugiyanto (2004), serta Tambunan dan Sitepu (2012). Dalam hal ini, karena adanya keterbatasan data, maka tidak semua variabel-variabel penentu daya saing yang terdapat pada ketiga teori tersebut digunakan sebagai variabel independen dalam menentukan daya saing sektor industri prioritas Indonesia. Adapun model persamaan yang digunakan adalah sebagai berikut:

$$
\begin{aligned}
\mathrm{DS}_{\mathrm{it}}= & \alpha-\beta_{1}(\mathrm{PX})_{\mathrm{it}}+\beta_{2} \operatorname{Ln}(\mathrm{LABPROD})_{\mathrm{it}}+ \\
& \beta_{3} \operatorname{Ln}(\text { FIXCAP })_{\mathrm{it}}+\beta_{4} \operatorname{Ln}(\mathrm{RER})_{\mathrm{it}}+ \\
& \varepsilon_{\mathrm{it}}
\end{aligned}
$$

dimana:

$$
\begin{array}{lrl}
\text { DS } & \text { Daya saing sektor industri } \\
& \text { prioritas Indonesia (nilai } \\
& \text { RCA) } ; \\
= & \text { Harga ekspor sektor industri } \\
& \text { prioritas Indonesia ke } \\
& \text { ASEAN (Ribu USD/Kg); } \\
& \text { LABPROD = } & \text { Produktivitas tenaga kerja } \\
& \text { pada sektor industri } \\
& \text { prioritas (Juta Rp); } \\
= & \text { Penambahan modal tetap } \\
& \text { (Miliar Rp); } \\
= & \text { Nilai tukar riil Rupiah } \\
& \text { terhadap Dolar (Rp/USD); } \\
= & \text { Variabel lain yang tidak } \\
\text { RER } & \text { dimasukkan ke dalam } \\
& \text { permodelan; } \\
= & \text { i adalah Sektor Industri } \\
& \text { Prioritas dan } \mathrm{t} \text { adalah } \\
& \text { periode waktu. }
\end{array}
$$

Berikut ini merupakan definisi operasional dari masing-masing variabel yang digunakan dalam penelitian: 
1. Daya Saing: merupakan hasil olah dari nilai ekspor sektor industri prioritas Indonesia terhadap total ekspor Indonesia yang selanjutnya dibandingkan dengan nilai ekspor sektor industri prioritas ASEAN terhadap total nilai ekspor ASEAN.

2. Harga Ekspor Sektor Industri Prioritas Indonesia: diperoleh dari hasil pembagian antara nilai ekspor sektor industri prioritas tersebut ke ASEAN secara keseluruhan dengan volume ekspor sektor industri prioritas tersebut ke ASEAN pada periode yang sama. Variabel ini menggambarkan harga sektor industri prioritas Indonesia yang diterima oleh konsumen pada harga dunia di tingkat tertentu. Harga ekspor juga merefleksikan biaya produksi yang dikeluarkan oleh produsen karena harga yang dikeluarkan oleh produsen merupakan harga pembelian input perusahaan eksportir untuk menghasilkan produk-produk yang diekspor, sehingga juga menentukan harga ekspornya.

3. Produktivitas Tenaga Kerja: adalah kemampuan tenaga kerja dalam menghasilkan barang produksi, yang dihitung berdasarkan rasio output dengan jumlah tenaga kerja yang dibayar.

4. Penambahan Modal Tetap: merupakan nilai penambahan modal tetap (fix capital) yang mencakup pembelian/penambahan, pembuatan dan perbaikan besar barang modal tetap (barang modal yang dapat digunakan dalam jangka panjang, lebih dari satu tahun yang digunakan dalam proses produksi atau kegiatan usaha, seperti tanah, gedung, mesin, kendaraan, dan sebagainya).

5. Nilai Tukar Riil (Rupiah terhadap Dollar): nilai yang digunakan saat menukar barang dari suatu negara dengan barang dari negara lain.
Untuk mendapatkan analisis data panel yang terbaik, maka pemilihan model dilakukan melalui Uji Chow dan Uji Hausman. Uji Chow digunakan untuk memilih antara model tanpa efek individu (common effect) atau model dengan efek individu (fixed effect dan random effect). Sementara itu, dalam memilih apakah fixed effect atau random effect yang lebih baik, dilakukan Uji Hausman (Firdaus 2011).

Dalam model panel juga diperlukan pengujian asumsi untuk mengetahui estimasi bias. Jika model yang terpilih berdasarkan uji Hausman adalah Random Effect Model (REM), maka estimasi dari model diasumsikan best linier unbiased estimator (BLUE) dan tidak perlu dilakukan pengujian terhadap tiga asumsi utama model BLUE (non-multicolinierity, homoskedasticity, dan non-autocorelation). Hal ini dikarenakan dua alasan, yaitu: (1) sifat data panel adalah bebas dari gejala multikolinieritas; dan (2) REM adalah model generalized least square (GLS), dan estimasi dengan menggunakan GLS secara otomatis sudah terbebas dari gejala autokorelasi, bahkan terbebas dari gejala heteroskedastisitas yang disebabkan variansi sisaannya konstan (Gujarati 2004). Jika model yang terpilih adalah Fixed Effect Model (FEM), maka perlu dilakukan pengujian terhadap asumsi sisaan, sebagai berikut:

\section{a. Uji Heteroskedastisitas}

Asumsi pertama yang harus dipenuhi dalam persamaan regresi adalah bahwa taksiran parameter dalam model regresi bersifat BLUE, maka varian $\left(\mathrm{u}_{\mathrm{i}}\right)$ harus sama dengan $\sigma^{2}$ (konstan), atau semua residual atau error memiliki varian yang sama, artinya plot residual dari model terpilih adalah menyebar konstan. Kondisi itu disebut dengan homoskedastisitas. Apabila varian tidak konstan atau berubah-ubah disebut dengan heteroskedastisitas. 


\section{b. Uji Autokorelasi}

Korelasi serial terjadi jika galat-galat dari observasi yang berbeda berkorelasi, dengan kata lain terjadi korelasi galat antar waktu. Jika galat-galat dari periode-periode waktu yang berbeda (biasanya berdekatan) berkorelasi, dikatakan bahwa galat itu berkorelasi serial. Korelasi serial biasanya terjadi pada data time series. Korelasi serial tidak mempengaruhi ketidakbiasan atau konsistensi penduga-penduga kuadrat terkecil biasa, tetapi mempengaruhi efisiensinya. Untuk mendeteksi ada atau tidaknya autokorelasi dapat digunakan uji Durbin Watson (DW), meliputi perhitungan uji statistik yang didasarkan pada residual-residual dari prosedur regresi kuadrat terkecil biasa.

\section{c. Uji Multikolinearitas}

Kolinearitas jamak muncul jika di antara variabel independen memiliki korelasi yang tinggi dan membuat kita sulit memisahkan efek satu variabel independen terhadap variabel dependen dari efek variabel independen yang lain, sehingga kesulitan dalam menafsirkan nilai penduga koefisien-koefisien regresi serta distribusi parameter regresi menjadi sangat sensitif terhadap korelasi yang terjadi antar variabel bebas dan galat baku regresi. Untuk melihat ada atau tidaknya multikolinieritas, dapat digunakan matriks koefisien korelasi antara masing-masing variabel independen. Rule of tumb yang digunakan untuk melihat ada atau tidaknya multikolinieritas adalah jika besarnya nilai korelasi dalam matriks tersebut lebih dari 0.8 , maka kemungkinan terdapat korelasi berganda. Selain itu, ciri lain yang menandakan adanya masalah multikolinieritas adalah terdapat nilai $\mathrm{R}^{2}$ (R-square) yang tinggi, namun banyak variabel independen yang tidak signifikan.

Selain uji asumsi, pengujian parameter model juga perlu dilakukan karena bertujuan untuk mengetahui kelayakan model dan apakah koefisien yang diestimasi telah sesuai dengan teori atau hipotesis. Pengujian parameter tersebut meliputi:

\section{a. Uji-F}

Uji-F digunakan untuk melakukan uji hipotesis koefisien (slope) regresi atau parameter model secara menyeluruh/bersamaan. Kriteria pengujiannya adalah jika nilai $\mathrm{F}$ observasi $>$ F tabel atau nilai probabilitas $F$-statistic $<$ taraf nyata $(\alpha)$, maka keputusan menolak $\mathrm{H}_{0}$ adalah signifikan. Dengan menolak $\mathrm{H}_{0}$ berarti minimal ada satu peubah bebas yang berpengaruh nyata terhadap peubah tak bebas.

b. Uji-t

Setelah melakukan uji koefisien regresi secara keseluruhan, maka langkah selanjutnya adalah menguji koefisien regresi secara parsial menggunakan uji-t. Hipotesis pada uji-t adalah : $\mathrm{H}_{0}: \beta_{\mathrm{i}}=0 \mathrm{Vs}$ $\mathrm{H}_{1}: \beta_{\mathrm{i}} \neq 0$. Keputusan dalam pengujian ini dilakukan dengan membandingkan nilai t-hitung dengan t-tabel atau dengan melihat nilai probabilitas dari t-hitung. Jika nilai t-hitung > t-tabel atau jika nilai probabilitas $\mathrm{t}<$ taraf nyata $(\alpha)$, maka keputusan menolak $\mathrm{H}_{0}$ adalah signifikan. Kesimpulannya adalah peubah bebas secara parsial signifikan mempengaruhi peubah tak bebas.

\section{c. Koefisien Determinasi $\left(\mathbf{R}^{2}\right)$}

Koefisien determinasi (Goodness of Fit) merupakan suatu ukuran yang penting dalam regresi, karena dapat menginformasikan baik atau tidaknya model regresi hasil estimasi. Nilai $\mathrm{R}^{2}$ mencerminkan seberapa besar variasi dari peubah bebas, $Y$ dapat diterangkan oleh peubah tak bebas, $X$. Jika $\mathrm{R}^{2}=0$, maka variasi dari $Y$ tidak dapat diterangkan oleh $X$ sama sekali, namun jika $\mathrm{R}^{2}=1$, maka variasi dari $Y$ secara keseluruhan dapat diterangkan oleh $X$. Semakin tinggi nilai koefisien determinasi, maka model akan semakin baik. 


\section{HASIL DAN PEMBAHASAN}

\section{Daya Saing Sektor Industri Prioritas Indonesia di Pasar ASEAN Berdasarkan Metode RCA}

Berdasarkan Tabel 1 dapat diketahui bahwa dalam periode tahun 2001-2013, terlihat bahwa lima dari delapan industri yang tergolong ke dalam sektor industri prioritas Indonesia yang meliputi industri Makanan dan Minuman, industri Tekstil, industri Pakaian Jadi, industri Kulit dan Barang dari Kulit serta industri Logam Dasar memiliki nilai RCA rata-rata di atas satu $(\mathrm{RCA}>1)$. Hal ini memiliki arti bahwa produk-produk dari kelima sektor industri prioritas tersebut memiliki keunggulan komparatif di pasar ASEAN dibandingkan dengan daya saing untuk jenis produk dari sektor industri yang sama di negara-negara ASEAN lainnya.

Tabel 1 Nilai RCA rata-rata sektor industri prioritas negara-negara ASEAN tahun 2001-2013

\begin{tabular}{lcccccccc}
\hline Negara & $\begin{array}{c}\text { Makanan } \\
\text { dan } \\
\text { Minuman }\end{array}$ & Tekstil & $\begin{array}{c}\text { Pakaian } \\
\text { Jadi }\end{array}$ & $\begin{array}{c}\text { Kulit } \\
\text { dan } \\
\text { Baran } \\
\text { g dari } \\
\text { Kulit }\end{array}$ & $\begin{array}{c}\text { Kimia dan } \\
\text { Barang-barang } \\
\text { dari Bahan } \\
\text { Kimia }\end{array}$ & $\begin{array}{c}\text { Logam } \\
\text { Dasar }\end{array}$ & $\begin{array}{c}\text { Mesin dan } \\
\text { Perlengkapan } \\
\text { nya }\end{array}$ & Furnitur \\
\hline Indonesia & 1.48 & 1.79 & 1.80 & 1.34 & 0.87 & 2.48 & 0.57 & 0.98 \\
Malaysia & 1.06 & 0.71 & 0.48 & 0.54 & 0.96 & 0.93 & 0.71 & 1.67 \\
Singapura & 0.35 & 0.56 & 1.01 & 0.77 & 1.10 & 0.76 & 1.40 & 0.90 \\
Philipina & 0.82 & 0.29 & 0.72 & 0.75 & 0.36 & 0.87 & 0.37 & 0.34 \\
Thailand & 1.91 & 1.76 & 0.82 & 1.58 & 1.24 & 0.74 & 1.00 & 0.64 \\
Kamboja & 0.73 & 1.91 & 5.00 & 0.86 & 0.11 & 2.03 & 0.65 & 0.51 \\
Vietnam & 3.10 & 2.55 & 2.11 & 3.30 & 0.42 & 1.16 & 0.30 & 0.83 \\
\hline
\end{tabular}

Sementara itu, untuk industri Kimia dan Barang-barang dari Bahan Kimia, industri Mesin dan Perlengkapannya serta industri Furnitur memiliki nilai RCA rata-rata kurang dari satu $(\mathrm{RCA}<1)$ yang artinya produk-produk dari ketiga industri tersebut tidak memiliki daya saing secara komparatif di pasar ASEAN. Hal ini dikarenakan ekspor produk-produk dari industri Kimia dan Barang-barang dari Bahan Kimia, industri Mesin dan Perlengkapannya serta industri Furnitur dari negara ASEAN lainnya ke pasar ASEAN memiliki nilai yang jauh lebih besar. Dengan kata lain, produk-produk yang dihasilkan oleh industri Kimia dan Barang-barang dari Bahan Kimia, industri Mesin dan Perlengkapannya serta industri Furnitur Indonesia kurang memilki kontribusi yang besar terhadap total ekspor ASEAN untuk komoditi yang sama, walaupun produk tersebut merupakan produk unggulan ekspor Indonesia.

\section{Faktor-faktor yang Mempengaruhi Daya Saing Sektor Industri Prioritas}

Berdasarkan Uji Chow dan Uji Hausman, model terbaik yang dipilih adalah Fixed Effect Model (FEM). Selain olah data dengan menggunakan FEM menghasilkan banyak variabel yang signifikan, koefisien dugaan yang dihasilkan dengan meggunakan model ini juga telah sesuai dengan teori. Model Fixed Effecf merupakan rnetode estimasi yang memperhitungkan adanya perbedaan antara setiap individu, yang dalam hal ini adalah 8 (delapan) industri prioritas. Pada model fixed effect ini diasumsikan bahwa slope adalah sama untuk semua industri, dengan kata lain pengaruh variabel bebas terhadap daya saing sebagai variabel 
terikat adalah sama untuk semua industri, sehingga tidak dapat dilihat pengaruh dari variabel-variabel bebas terhadap daya saing di masing-masing industri prioritas.

Hal ini merupakan salah satu keterbatasan dari pendekatan fixed effect. Satu hal yang membedakan hanyalah pada nilai intercept-nya, dimana nilai intercept yang berbeda-beda ini diasumsikan berasal dari variabel yang tidak ikut masuk sebagai variabel bebas dalam persamaan regresi yang dikenal sebagai omitted variable.

Pada pengolahan data ini sengaja dilakukan pembobotan untuk mengantisipasi pelanggaran asumsi yang terjadi. Pembobotan yang dilakukan adalah dengan menggunakan General Least Square (GLS). Selain itu, pembobotan Seemingly Unrelated Regression (SUR) juga dilakukan guna mengantisipasi adanya masalah heteroskedastisitas dan autokorelasi antara individu dalam data panel.Selain itu, juga dilakukan uji asumsi dan deteksi normalitas. Asumsi yang harus dipenuhi dalam persamaan regresi data panel adalah bahwa estimasi parameter dalam model regresi bersifat BLUE (Best Linier Unbiased Estimate), maka ragam error harus konstan atau semua error mempunyai varian yang sama. Kondisi ini disebut homoskedastisitas. Adapun jika ragam error tidak konstan atau berubah-ubah, maka disebut heteroskedastisitas. Berdasarkan hasil pengamatan nilai sum square residual, tidak ditemukan adanya heteroskedastisitas pada model karena nilai sum square residual pada weighted statistics (98.75999) lebih besar daripada nilai sum square residual pada unweighted statistics (32.56928). Selain itu, untuk mendeteksi ada atau tidaknya heteroskedastisitas juga dapat dilakukan dengan melihat plot residual.

Berdasarkan plot residual pada Gambar 2 juga dapat dilihat bahwa sebaran residual menyebar konstan. Dengan demikian, dapat disimpulkan sudah homoskedastisitas atau tidak terdapat masalah heteroskedastisitas.

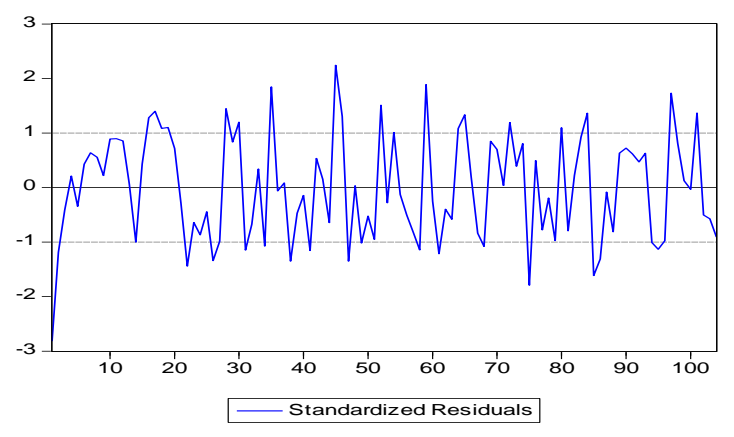

Gambar 2 Plot Residual pada FEM

Pendeteksian adanya autokorelasi juga dilakukan pada model ini. Untuk mendeteksi adanya autokorelasi dilakukan dengan membandingkan Durbin Watson (DW) statistiknya dengan DW-Tabel. Berdasarkan hasil pengujian pada model menunjukkan bahwa nilai DW-Statistiknya adalah sebesar 1.693559. Dengan nilai dL sebesar 1,5597 dan nilai dU sebesar 1,7493, maka nilai DW-Stat ini terletak di "daerah keragu-raguan" yang artinya kemungkinan tidak terdapat permasalahan autokorelasi pada model.

Asumsi lainnya yang harus dipenuhi adalah model terbebas dari masalah multikolinearitas, yaitu tidak adanya korelasi antar variabel bebas. Uji ini dilakukan dengan melihat matriks korelasi antara variabel-variabel independen, dimana rule of tumb yang digunakan adalah 0.8. Jika nilai korelasi lebih besar dari 0.8, maka dapat dikatakan terdapat masalah multikolinearitas pada persamaan regresi. Berdasarkan matriks korelasi antara variabel-variabel independen yang dapat dilihat pada Tabel 2, diketahui tidak terdapat korelasi yang kuat antara variabel indpenden. Hal ini menandakan bahwa tidak terdapat permasalahan multikolinearitas pada model. 
Tabel 2 Matriks Korelasi Antar Variabel Bebas

\begin{tabular}{lrrrr}
\hline & \multicolumn{1}{c}{ PX } & LABPROD & FIXCAP & \multicolumn{1}{c}{ RER } \\
\hline PX & 1 & -0.412 & 0.042 & -0.219 \\
LABPROD & -0.412 & 1 & 0.042 & -0.221 \\
FIXCAP & 0.042 & 0.042 & 1 & -0.302 \\
RER & -0.219 & -0.221 & -0.302 & 1 \\
\hline
\end{tabular}

Selain uji asumsi, juga dilakukan deteksi normalitas pada model yang bertujuan untuk menguji apakah residual terdistribusi secara normal atau tidak.

Hasil regresi yang baik memerlukan residual yang normal dalam penarikan kesimpulan hasil estimasi. Adapun hipotesis pada deteksi normalitas adalah sebagai berikut:

$\mathrm{H}_{0}$ : Residual menyebar normal

$\mathrm{H}_{1}$ : Residual tidak menyebar normal

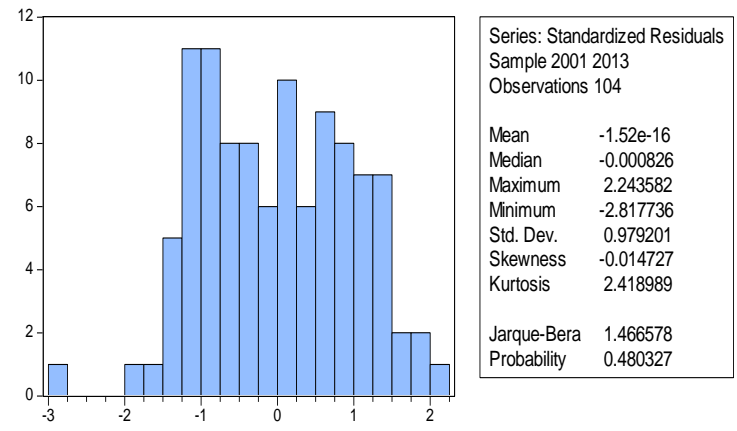

Gambar 3 Deteksi Normalitas

Berdasarkan Gambar 3, nilai probability $(0.480327)>0.05$ (taraf nyata 5 persen), maka keputusannya adalah terima Hipotesis $\mathrm{Nol}\left(\mathrm{H}_{0}\right)$ yang artinya asumsi residual menyebar normal terpenuhi.

Hasil signifikansi koefisien menggunakan data panel terhadap masing-masing sektor industri prioritas dalam periode waktu 11 tahun tersaji pada Tabel 3. Berdasarkan hasil regresi panel dengan pendekatan fixed effect, terlihat bahwa variabel bebas yang signifikan mempengaruhi daya saing sektor industri prioritas adalah harga ekspor, produktivitas tenaga kerja dan nilai tukar riil. Hasil ini dibuktikan dengan nilai probabilitas pada masing-masing variabel bebas tersebut lebih kecil daripada taraf nyata 5 persen. Hasil uji kecocokan model (goodness of fit) dilihat dari nilai koefisien determinasi $\left(\mathrm{R}^{2}\right)$. Dengan nilai $R$-squared $\left(\mathrm{R}^{2}\right)$ sebesar 0.933883 model ini mampu memprediksi 93 persen variasi dari variabel dependennya, sedangkan sisanya dijelaskan oleh faktor lain di luar model. Selanjutnya, akan dijelaskan lebih detail mengenai hubungan antara masing-masing variabel independen dengan variabel dependen.

Tabel 3 Hasil estimasi faktor-faktor yang mempengaruhi daya saing sektor industri prioritas Indonesia

\begin{tabular}{lrc}
\hline \multicolumn{1}{c}{ Variabel } & Koefisien & Probabilitas \\
\hline PX (Harga Ekspor) & -5.261890 & 0.0000 \\
LABPROD (Produktivitas TK) & 0.026079 & 0.0403 \\
FIXCAP (Modal) & -0.023866 & 0.2213 \\
RER (Nilai Tukar Riil) & 0.556836 & 0.0000 \\
C (Konstanta) & -4.824985 & 0.0000 \\
\hline R-squared & 0.943883 & \\
Adjusted R-squared & 0.937173 & \\
Prob(F-statistic) & 0.000000 & \\
\hline
\end{tabular}




\section{Harga Ekspor (PX)}

Harga ekspor pada dasarnya dihasilkan dari permintaan dan penawaran produk dari sektor industri prioritas Indonesia di pasar ASEAN. Pada periode tahun 2005 hingga 2013, kinerja ekpor industri manufaktur Indonesia yang menjadi prioritas pemerintah ke negara-negara ASEAN menunjukan tren yang berfluktuatif karena pengaruh globalisasi dan dampak perekonomian yang terjadi pada perdaganganan internasional maupun regional seperti terlihat pada Gambar 4. Pengaruh resesi ekonomi yang terjadi di Uni Eropa dan bergerak ke Amerika pada tahun 2007-2008 tidak dirasakan para produsen/ pengusaha di Indonesia, khususnya pada sektor industri prioritas. Hal itu terlihat dari tren naik dari industri prioritas pada tahun tersebut yang menyumbang besar bagi pertumbuhan ekonomi Indonesia. Namun, krisis ekonomi di akhir tahun 2008 dirasakan dampaknya pada iklim usaha Indonesia pada tahun 2009 dengan turunnya pertumbuhan laju ekspor produk-produk pada sektor industri prioritas Indonesia seiring dengan menurunya permintaan terhadap produk dari industri prioritas Indonesia. Serangkaian kebijakan dan regulasi telah dibuat untuk menghadapi pengaruh krisis ekonomi global ini dan berdampak positif untuk iklim usaha sehingga mampu membuat jumlah nilai ekspor Indonesia rebound dan bahkan melebihi dari tahun sebelum terkena dampak resesi.

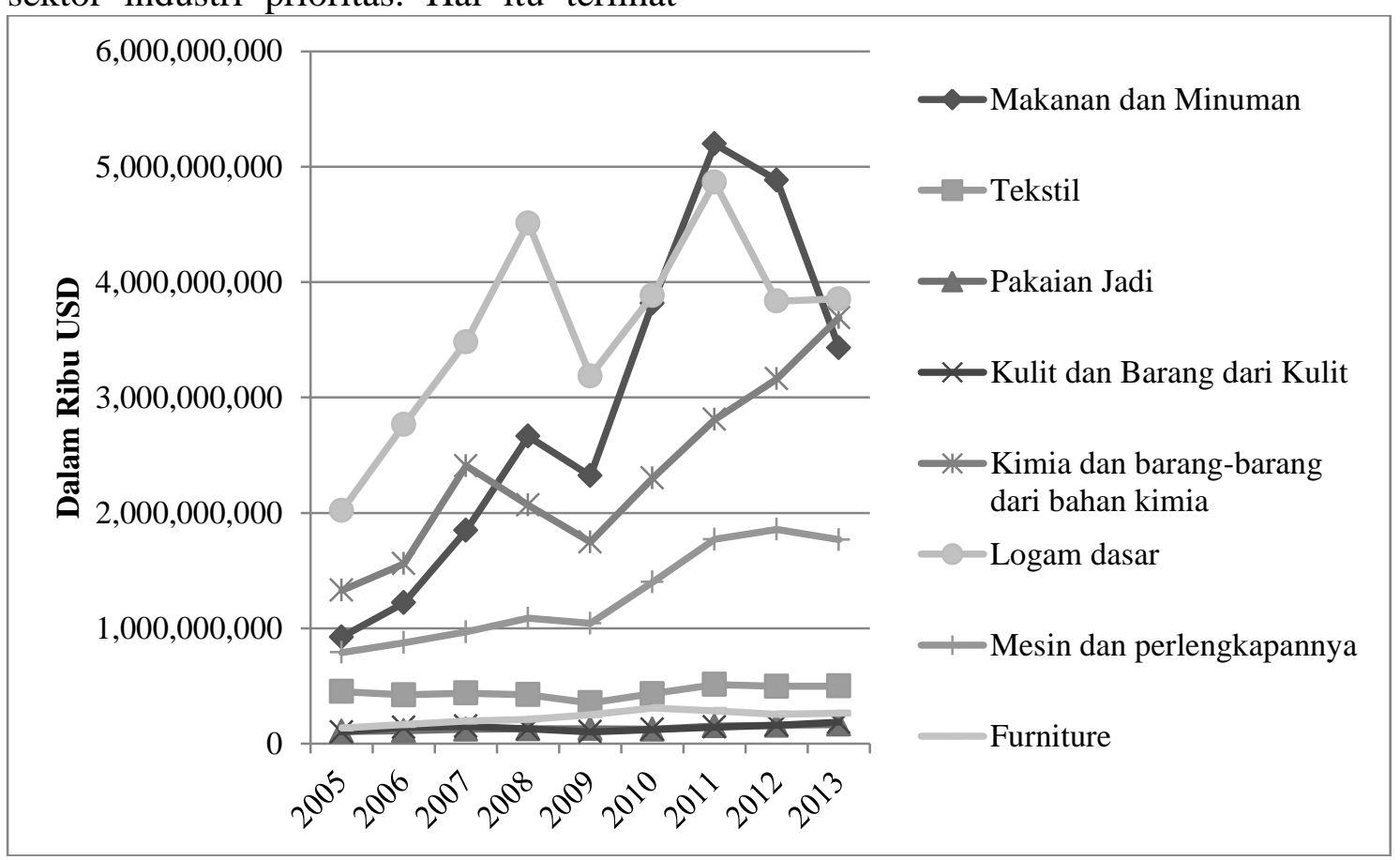

Sumber: WITS 2015 (diolah)

Gambar 4 Ekspor sektor industri prioritas Indonesia ke kawasan ASEAN tahun 2005-2013

Disisi lain, terjadinya impor atas kelompok industri yang sama dari negara anggota ASEAN adalah konsekuensi logis dari keputusan Indonesia untuk memasuki AFTA pada tahun 2002 dalam perdagangan kawasan regional ASEAN. Komitmen penghapusan hambatan perdagangan, khususnya tarif, mendorong negara-negara anggota ASEAN untuk mengimpor komoditas atau produk dari 
negara anggota FTA yang berbiaya lebih rendah daripada membeli dari industri domestik yang berbiaya tinggi. Sebagai hasilnya, terjadi impor atas produk yang berspesifikasi teknis yang sama tetapi relatif lebih murah, atau terjadi impor karena dekatnya daerah yang membutuhkan produk tersebut ke sumber produksi (metode kedekatan geografi dati teori gravitasi). Adapun produk-produk pada beberapa industri prioritas yang menghasilkan net ekspor, antara lain Tekstil dan Produk Tekstil/TPT (dari Thailand), produk kulit dan barang-barang dari kulit (dengan Thailand dan Vietnam), mesin dan perlengkapannya (dengan Malaysia, Myanmar, Philipina, Singapura dan Thailand) dan Furnitur (dengan Philipina dan Thailand). Dengan demikian, secara total dari tahun 2005 sampai dengan tahun 2013, Indonesia mengalami defisit neraca perdagangan dengan Thailand. Ini semua menunjukkan bahwa Free Trade Agreement di kawasan ASEAN menciptakan trade creation karena membuka kesempatan kepada pelaku ekonomi di masing-masing negara anggota untuk medapatkan produk atau komoditi yang lebih murah, baik dari segi biaya produksi atau karena dihapuskannya biaya tarif ekspor.

Rendahnya harga ekspor mencerminkan bahwa produk-produk pada industri prioritas berdaya saing. Dalam hal ini salah satu komponen yang mempengaruhi harga ekspor adalah harga domestik di tingkat produsen yang biasa dikenal juga dengan harga relatif, yaitu biaya produksi yang dikeluarkan oleh industri untuk membentuk suatu macam produk, baik itu kualitas, desain, harga dan lain sebagainya. Tingkat harga relatif yang semakin rendah, menunjukkan rendahnya biaya produksi yang dikeluarkan oleh perusahaan atau industri, dan itu menunjukkan tingkat daya saing perusahaan yang semakin tinggi.
Rendahnya biaya produksi menandakan bahwa harga pembelian input oleh perusahaan eksportir juga rendah, sehingga harga ekspornya pun rendah. Karena esensi daya saing adalah biaya yang relatif rendah, maka rendahnya harga ekspor produk-produk pada industri prioritas menunjukkan daya saingnya yang semakin meningkat. Begitu pula sebaliknya, tingginya harga ekspor produk-produk pada industri prioritas menunjukkan daya saingnya yang semakin menurun.

Hasil regresi berdasarkan pendekatan fixed effect menunjukkan bahwa variabel harga ekspor (PX) secara statistik signifikan dalam menentukan daya saing (DS) sektor industri prioritas dan memiliki hubungan yang negatif. Hasil ini sesuai dengan hipotesis penelitian dan penjelasan di atas, dimana jika harga ekspor meningkat, tingkat daya saing justru mengalami penurunan. Nilai koefisien variabelnya sebesar $-5,26$ berarti bahwa apabila harga ekspor produk dari sektor industri prioritas naik sebesar 1 persen dengan asumsi variabel lainnya tetap (cateris paribus), maka daya saing sektor industri prioritas akan turun sebesar 5,26 persen.

\section{Produktivitas Tenaga Kerja (LABPROD)}

Pada sektor industri prioritas Indonesia, peningkatan produktivitas tenaga kerja dilakukan melalui beberapa cara, di antaranya dengan meningkatkan upah tenaga kerja, seperti pada industri Makanan dan Minuman, industri Kimia dan Barang-barang dari Bahan Kimia, industri Logam Dasar serta industri Mesin dan Perlengkapannya. Selain itu, dapat juga dilakukan melalui pelatihan-pelatihan untuk meningkatkan kemampuan para tenaga kerja berupa pelatihan teknis bagi SDM industri dan pendampingan tenaga ahli, seperti yang diberlakukan pada industri Tekstil, Pakaian Jadi, Kulit dan 
Barang dari Kulit serta industri Furnitur (Kemenperin 2013).

Upaya peningkatan produktivitas tenaga kerja melalui beberapa cara tersebut dilakukan mengingat bila dibandingkan dengan beberapa negara ASEAN, produktivitas tenaga kerja di industri manufaktur Indonesia masih tergolong rendah. Menurut data Asian Productivity Organization/APO (2013), produktivitas tenaga kerja Indonesia di sektor industri manufaktur adalah sebesar 9.500 USD. Jika diasumsikan 1 USD sama dengan Rp 11.000, maka produktivitas tenaga kerja Indonesia setara dengan Rp 104,5 juta per pekerja per tahun. Angka produktivitas tenaga kerja Indonesia ini di bawah Singapura yang mencapai 92.000 USD atau Rp 1.012 miliar, Malaysia 33.300 USD atau Rp 363,3 juta, dan Thailand 15.400 USD atau Rp 169,4 juta. Bahkan, produktivitas tenaga kerja Indonesia berada di bawah rata-rata ASEAN yang sebesar 10.700 USD atau Rp 117,7 juta. Selain itu, data dari Kamar Dagang dan Industri (Kadin) Indonesia juga menunjukkan bahwa tingkat produktivitas tenaga kerja industri manufaktur di Indonesia berada jauh di bawah beberapa negara ASEAN lainnya, yaitu di peringkat ke-59 dibandingkan Thailand di peringkat ke-27 dan Malaysia di peringkat ke-18.

Ikut sertanya Indonesia ke dalam integrasi ekonomi ASEAN menyebabkan semakin besarnya ukuran pasar dan persaingan yang dihadapi sektor industri prioritas Indonesia. Oleh karena itu, industri-industri yang tergolong ke dalam sektor prioritas akan terdorong untuk meningkatkan efisiensinya melalui peningkatan produktivitas tenaga kerjanya agar dapat bersaing dengan industri sejenis dari negara ASEAN lainnya.

Data BPS (2015) menunjukkan bahwa industri prioritas yang tingkat produktivitas tenaga kerjanya paling tinggi adalah industri Logam Dasar. Hal ini berarti bahwa peningkatan upah tenaga kerja sebagai strategi peningkatan produktivitas tenaga kerja yang dilakukan oleh industri ini sangat dirasakan pengaruhnya. Seperti diketahui bahwa suatu perusahaan akan menghasilkan output yang lebih banyak dengan mempekerjakan tenaga kerja dengan produktivitas yang lebih tinggi, sehingga perusahaan akan bersedia memberikan upah/gaji yang lebih tinggi kepada tenaga kerja yang bersangkutan. Pada akhirnya, peningkatan produktivitas tenaga kerja ini akan berimbas pada peningkatan daya saingnya. Hal ini dapat dibuktikan dari nilai RCA industri Logam Dasar yang menunjukkan bahwa industri ini memiliki daya saing tertinggi bila dibandingkan dengan industri prioritas lainnya.

Sementara itu, industri prioritas yang tingkat produktivitas tenaga kerjanya paling rendah adalah industri Pakaian Jadi. Peningkatan kualitas sumber daya manusia yang belum sesuai dengan kebutuhan industri menjadi salah satu penyebabnya (Kemenperin 2015). Meskipun industri ini berdaya saing di pasar ASEAN, namun jika produktivitas tenaga kerjanya tidak ditingkatkan, maka sangat memungkinkan hal tersebut dapat berimbas pada penurunan daya saingnya.

Hasil regresi panel dengan pendekatan fixed effect menunjukkan bahwa variabel produktivitas tenaga kerja (LABPROD) berpengaruh signifikan terhadap variabel daya saing (DS) sektor industri prioritas. Nilai koefisien variabel LABPROD sebesar 0,03 berarti peningkatan produktivitas tenaga kerja di sektor industri prioritas sebesar 1 persen dengan asumsi variabel lainnya tetap (cateris paribus) akan meningkatkan daya saing di sektor industri prioritas sebesar 0,03 persen. Hasil ini sesuai dengan beberapa penelitian sebelumnya, antara lain yang dilakukan oleh Bloch dan McDonald (2000) di Australia serta Sjoholm (1997) di Indonesia yang menyebutkan bahwa terdapat hubungan 
positif antara liberalisasi perdagangan dengan produktivitas tenaga kerja. Dalam hal ini, semakin terbukanya perdagangan Indonesia ke kawasan ASEAN, menandakan semakin tingginya persaingan produk-produk yang dihasilkan oleh sektor industri prioritas Indonesia dengan produk sejenis dari negara ASEAN lainnya. Hal ini menyebabkan produsen di sektor industri prioritas Indonesia harus berusaha mendorong peningkatan produktivitasnya agar dapat bertahan di tengah persaingan dengan produk asing.

\section{Penambahan Modal Tetap (FIXCAP)}

Modal juga merupakan salah satu input yang penting untuk digunakan dalam proses produksi. Karena modal diperlukan untuk menghasilkan output, maka semakin banyak modal yang tersedia, diharapkan output yang dihasilkan pun akan semakin besar. Dengan demikian, dapat mendorong peningkatan daya saing di sektor industri prioritas.

Sumber daya modal dalam hal ini berupa mesin-mesin atau peralatan dan bahan baku yang digunakan sebagai input dalam proses produksi. Menurut data Kemenperin (2013), total nilai penanaman modal di sektor manufaktur secara umum mencapai Rp 160 triliun pada 2012, jauh di atas target awal tahun 2012 yaitu sebesar Rp 120 triliun. Sedangkan investasi di sektor manufaktur tahun 2013 mencapai Rp 223.648 triliun.

Bagi industri Makanan dan Minuman, dari sisi investasi, sepanjang Januari-September 2013 tercatat penanaman modal dalam negeri (PMDN) di industri Makanan dan Minuman mencapai $\mathrm{Rp} 7,71$ triliun dengan 176 proyek. Sementara, penanaman modal asing (PMA) tercatat sebesar 1.14 miliar USD dengan 334 proyek pada periode Januari-September 2013. Gabungan Pengusaha Makanan dan Minuman Indonesia (GAPMMI) memperkirakan investasi di sektor Makanan dan Minuman nasional bisa mencapai $\mathrm{Rp} 25$ triliun. Sekitar 60 persen diantaranya merupakan investasi di industri minuman ringan. Nilai omzet industri Makanan dan Minuman tahun 2014 tumbuh 8 persen menjadi sekitar Rp 760 triliun. Sub sektor minuman mengalami pertumbuhan tertinggi, yaitu naik sebesar 15 persen, sedangkan untuk sub sektor makanan hanya tumbuh sebesar 8 persen (Kemenperin 2015).

Pada industri Tekstil dan Pakaian Jadi, kebutuhan bahan baku berupa kain diperkirakan mencapai 2,1 juta ton per tahun, sementara kapasitas produksi industri kain mencapai 2,5 juta ton per tahun. Dengan jumlah kapasitas produksi tersebut, seharusnya kebutuhan produk kain dapat dipenuhi oleh industri dalam negeri, namun pada kenyataannya impor kain mencapai 615 ribu ton yang diperkirakan setara dengan 1,53 miliar meter atau sebesar 29 persen dari kebutuhan kain domestik di tahun 2014. Oleh karena itu, diharapkan dengan adanya program restrukturisasi mesin dan peralatan industri yang telah berlangsung selama delapan tahun belakangan ini, industri Tekstil dan Pakaian Jadi nasional memiliki kemampuan untuk meningkatkan daya saingnya. Pada tahun 2015 ini, anggaran restrukturisasi mesin tekstil yang disediakan pemerintah sekitar $\mathrm{Rp} 100$ miliar, dan program tersebut masih akan dibutuhkan setidaknya hingga lima tahun ke depan. Dengan peremajaan mesin tekstil, maka proses produksi bisa berjalan lebih efisien, sehingga daya saing produk tekstil bisa dijaga dan ditingkatkan (Kemenperin 2015).

Untuk industri Kimia dan Barang-barang dari Bahan Kimia, salah satu produsen petrokomia terbesar di Indonesia, yaitu PT. Asahimas Chemical telah menginvestasikan dananya sebesar 300 - 400 juta USD (sekitar Rp 3,8 triliun) pada akhir tahun 2014. Dana tersebut dialokasikan untuk ekspansi pabrik pengolahan soda kaustik dan polyvinyl 
chloride (PVC) yang berlokasi di Cilegon, Banten. Ekspansi dimaksud telah mulai dilakukan pada akhir tahun 2014 dan akan mulai beroperasi pada akhir 2015. Perluasan pabrik yang akan menyerap 300 tenaga kerja baru ini dipicu oleh pertumbuhan ekonomi Indonesia yang sebesar 6 sampai 7 persen per tahun dan kebutuhan industri yang semakin meningkat. Ekspansi tersebut bertujuan untuk memenuhi kebutuhan industri di dalam negeri, terutama untuk sektor-sektor industri seperti sabun, makanan dan pakaian. Ekspansi itu akan menambah kapasitas produksi soda kaustik dari sebesar 500 ribu ton per tahun menjadi 700 ribu ton per tahun dan PVC dari 250 ribu ton menjadi 600 ribu ton per tahun. Ekspansi ini juga akan memperbesar porsi ekspor produk soda kaustik dan PVC. Terkait bahan baku, kebutuhan PT. Asahimas Chemical saat ini dipasok dari dalam negeri dan diimpor dari Timur Tengah. Saat ini, 80 persen produksi dari industri kimia Indonesia digunakan untuk kebutuhan dalam negeri dan 20 persen sisanya diekspor. Ekspansi PT. Asahimas akan memperkuat sektor industri kimia nasional khususnya bagi produk PVC dan soda kaustik. Sektor swasta lainnya yang juga berinvestasi di industri kimia Indonesia adalah PT. Honam Pertrochemical Corporation yang berasal dari Korea Selatan. Menurut Kemenperin, investasi Honam cukup besar dan bisa membantu Indonesia keluar dari ketergantungan impor bahan kimia. Selain sektor swasta, peranan dari pemerintah juga dibutuhkan. Guna menunjang peningkatan daya saing industri kimia, pemerintah melalui Pertamina mengerjakan proyek investasi di sektor hulu. Diharapkan dengan investasi di sektor hulu yang tersedia saat ini, yaitu sebesar 5 miliar USD dapat memenuhi kebutuhan domestik dalam lima tahun ke depan (Kemenperin 2013).
Pada industri Logam Dasar, menurut data Kemenperin (2013), ada sembilan perusahaan yang melakukan investasi maupun ekspansi di sektor industri Logam Dasar. Kesembilan perusahaan tersebut, antara lain adalah PT. KS Posco dengan nilai investasi sebesar 3 miliar USD, Nippon dan KS senilai 300 juta USD, perusahaan Jepang sebesar 300 juta USD, ekspansi oleh KS sebesar 140 juta USD, PT Delta Prima sebesar 40 juta USD, Indoferro 140 juta USD, Weda Bay Nikel senilai 5 miliar USD dan Feni Haltim sebesar 1,6 miliar USD. Data Kemenperin (2013) juga menunjukkan bahwa kebutuhan pasar domestik akan produk logam dasar diperkirakan akan terus mengalami peningkatan sekitar 8-9 persen per tahun. Konsumsi logam dasar perkapita yang banyak digunakan sebagai material utama pembangunan infrastruktur, gedung, bangunan hingga jalanan dan jembatan juga diperkirakan akan bertambah menjadi 57 kilogram $(\mathrm{kg})$ pada tahun 2015 ini dari tahun 2010 yang sebesar $48 \mathrm{~kg}$. Dengan adanya investasi dari kesembilan perusahaan tersebut diharapkan mampu mensubstitusi kebutuhan pasar domestik sebesar 6.8 juta ton per tahun dari impor saat ini yang mencapai 9 juta ton per tahun (Kemenperin 2013).

Pada industri Mesin dan Perlengkapannya, di tahun 2015 ini mengalami peningkatan produksi sebesar 8,60 persen. Peningkatan ini terutama ditopang oleh tumbuhnya investasi penanaman modal asing yang naik sebesar 101,9 persen dan investasi penanaman modal dalam negeri yang juga tumbuh sebesar 52,5 persen. Dari tingkat pertumbuhan modal tersebut terlihat bahwa pada industri Mesin dan Perlengkapannya masih mengalami ketergantungan terhadap persediaan modal asing (BPS 2015). 
Di sisi lain, industri Furnitur yang dianggap telah mampu berdaya saing di pasar ASEAN, tidak lain karena didukung dengan sumber bahan baku yang memiliki keragaman corak desain yang inovatif dan menarik. Ketergantungan industri Furnitur Indonesia yang tinggi terhadap bahan baku yang berasal dari dalam negeri tidak ditunjang dari ketersediaannya. Hal ini sebagaimana dinyatakan dalam Roadmap Industri Furnitur (2009), industri Furnitur Indonesia menghadapi kesenjangan antara pasokan dan kebutuhan bahan baku (Kayu dan Rotan) yang semakin melebar. Kesenjangan ini akibat dari masih maraknya praktek illegal logging pada hutan alam dan illegal trade. Di samping itu, masih belum optimalnya dukungan pasokan bahan baku dari Hutan Tanaman Industri (HTI) dan Hutan Rakyat (HR). Bersamaan dengan sulitnya mendapatkan bahan baku kayu untuk industri, juga masih belum banyak industri yang memanfaatkan bahan baku alternatif non hutan alam sebagaimana kayu kelapa, kayu kelapa sawit dan kayu karet (tua). Ketidaktersediaan bahan baku lokal dan mahalnya harga bahan baku lokal dianggap menjadi hambatan bagi industri Furnitur Indonesia dalam bersaing dengan produk sejenis dari negara ASEAN lainnya (Kemendag 2011).

Hasil regresi berdasarkan pendekatan fixed effect menunjukkan bahwa variabel penambahan modal tetap (FIXCAP) tidak signifikan terhadap variabel daya saing (DS) di sektor industri prioritas. Hal ini disebabkan karena dampak terhadap peningkatan daya saing dari adanya penambahan modal tetap pada tahun tertentu tidak langsung dirasakan pada tahun tersebut, melainkan akan dirasakan pada beberapa tahun ke depan.

Seperti halnya telah dijelaskan di atas bahwa adanya penanaman investasi, baik dari dalam negeri maupun luar negeri, adanya program restrukturisasi mesin dan peralatan industri, adanya perluasan pabrik dan lain sebagainya merupakan upaya peningkatan daya saing industri di masa depan yang dilakukan pada saat sekarang.

\section{Nilai Tukar Riil (RER)}

Besarnya nilai daya saing sektor industri prioritas Indonesia cukup dipengaruhi oleh nilai ekspor dan total ekspornya, dimana keduanya sangat bergantung pada perubahan nilai tukar Rupiah terhadap Dollar Amerika Serikat. Hal tersebut dapat terjadi karena nilai RCA yang ada dipengaruhi oleh nilai ekspor yang dihitung dalam Dollar Amerika Serikat, sehingga menguat atau melemahnya nilai tukar Rupiah terhadap Dollar Amerika Serikat sangatlah penting pengaruhnya terhadap daya saing sektor industri prioritas Indonesia.

Hasil regresi panel dengan pendekatan fixed effect menunjukkan bahwa variabel nilai tukar riil (RER) secara statistik berpengaruh signifikan terhadap daya saing (DS) sektor industri prioritas. Nilai koefisiennya sebesar 0.56 berarti bahwa jika nilai tukar riil meningkat sebesar 1 persen dengan asumsi variabel lainnya tetap (cateris paribus), maka daya saing di sektor industri prioritas akan meningkat sebesar 0.56 persen.

Di sisi lain, pada industri manufaktur, Di sisi lain, pada industri manufaktur, khususnya sektor industri prioritas yang sebagian besar inputnya merupakan komponen impor, kenaikan nilai tukar dapat menyebabkan peningkatan beban ongkos atau biaya produksi. Ketergantungan impor yang tinggi membuat industri prioritas sangat rentan terhadap fluktuasi nilai tukar Rupiah. Industri prioritas yang paling sensitif terhadap depresiasi Rupiah adalah industri Mesin dan Perlengkapanya, baik dalam hal penurunan output maupun tekanan di sisi biaya. Ekspor pada industri tersebut tidak dapat tumbuh optimal saat Rupiah terdepresiasi karena terdapat tekanan dari sisi biaya produksi akibat 
besarnya kenaikan harga bahan baku dan barang modal yang berasal dari impor, sehingga terjadi lonjakan impor yang melebihi pertumbuhan ekspornya yang pada akhirnya menyebabkan terjadi defisit neraca perdagangan. Kondisi ini sangat mengkhawatirkan karena ketika Rupiah terdepresiasi, pertumbuhan ekspor manufaktur justru melambat. Padahal, depresiasi Rupiah seharusnya mendorong pertumbuhan ekspor yang pada gilirannya dapat meningkatkan daya saing.

Dari regresi dengan menggunakan pendekatan fixed effect, juga diperoleh hasil intercept untuk masing-masing industri yang dijadikan sebagai variabel cross section atau dapat disebut sebagai individual effect (Tabel 4). Berdasarkan nilai intercept untuk setiap industri prioritas, dapat diketahui perbedaan tingkat daya saing antara satu industri dengan industri lainnya sehingga dapat dilihat tingkat daya saing masing-masing industri secara terpisah. Adapun urutan sektor industri prioritas mulai dari yang memiliki nilai daya saing tinggi sampai dengan yang nilai daya saingnya rendah berdasarkan nilai intercept-nya adalah sebagai berikut: (1) industri Logam Dasar, (2) industri Pakaian Jadi, (3) industri Tekstil, (4) industri Kulit dan Barang dari Kulit, (5) industri Makanan dan Minuman, (6) industri Furnitur, (7) industri Kimia dan Barang-barang dari Bahan Kimia dan (8) industri Mesin dan Perlengkapannya. Penetapan peringkat daya saing sektor industri prioritas berdasarkan nilai intercept tersebut adalah in line atau sesuai dengan hasil analisis daya saing dengan menggunakan RCA. Industri yang memiliki tingkat daya saing tertinggi berdasarkan hasil RCA dan nilai intercept adalah industri Logam Dasar. Sementara itu, ketiga industri prioritas dengan urutan terbawah berdasarkan nilai intercept, yaitu industri Furnitur, industri Kimia dan Barang-barang dari Bahan Kimia serta industri Mesin dan Perlengkapannya merupakan industri yang tidak berdaya saing berdasarkan hasil analisis RCA.

Tabel 4 Nilai intercept pada masing-masing sektor industri prioritas Indonesia

\begin{tabular}{lc}
\hline \multicolumn{1}{c}{ Sektor Industri } & Nilai Intercept \\
\hline Makanan dan Minuman & $-4,72$ \\
Tekstil & $-4,56$ \\
Pakaian Jadi & $-4,36$ \\
Kulit dan Barang dari Kulit & $-4,66$ \\
Kimia dan Barang-barang dari Bahan Kimia & $-5,29$ \\
Logam Dasar & $-4,27$ \\
Mesin dan Perlengkapannya & $-5,62$ \\
Furnitur & $-5,12$ \\
\hline
\end{tabular}

\section{Analisis Kebijakan Peningkatan Daya Saing Sektor Industri Prioritas Indonesia}

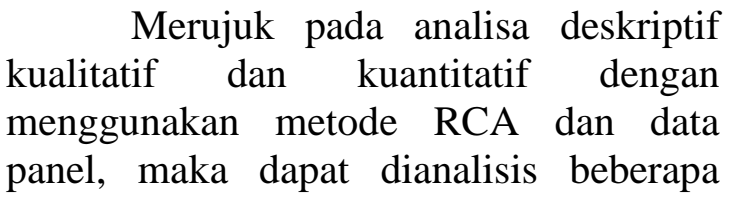

kebijakan dalam rangka meningkatkan daya saing sektor industri prioritas Indonesia di kawasan ASEAN. Pertama, terkait dengan harga ekspor, kebijakan pengembangan industri hulu dan industri antara berbasis sumber daya alam serta pengendalian ekspor bahan mentah dirasa perlu dilakukan mengingat Indonesia kaya 
akan hasil alam, baik yang dapat diperbaharui maupun yang tidak dapat diperbaharui. Pengurangan ekspor hasil alam berupa bahan mentah yang kemudian dialokasikan untuk bahan baku industri domestik, diharapkan dapat mengurangi ketergantungan terhadap bahan baku impor. Dengan demikian, biaya produksi dapat lebih murah dan pada akhirnya dapat berdampak pada rendahnya harga ekspor.

Harga ekspor pada dasarnya dihasilkan dari adanya permintaan dan penawaran produk dari sektor indusri prioritas Indonesia di pasar ASEAN. Berdasarkan hal tersebut, kabijakan kedua yang dapat diterapkan terkait dengan pengembangan ekspor sektor industri prioritas ke kawasan ASEAN adalah melalui peningkatan nilai tambah produk pada industri prioritas melalui kegiatan diversifikasi produk, dan meningkatkan pola kerjasama dengan produsen negara lain di kawasan ASEAN melalui promosi, sehingga dapat mendukung kegiatan diversifikasi pasar tujuan ekspor untuk produk-produk yang dihasilkan oleh sektor industri prioritas Indonesia ke arah yang lebih prospektif. Salah satu upaya yang dapat dilakukan guna mendukung strategi tersebut adalah dengan aktif ikut serta dalam pameran internasional. Selain dapat menjadi ajang promosi untuk memperluas akses pasar, diharapkan juga dapat terjalin kerjasama antara stakeholder industri prioritas sehingga mampu meningkatkan nilai perdagangan yang dapat memberikan manfaat besar bagi sektor industri prioritas Indonesia sekaligus mendorong pengembangan industri nasional secara umum.

Ketiga, kebijakan yang berhubungan dengan peningkatan produktivitas tenaga kerja berupa peningkatan kualitas SDM pelaku industri pada sektor industri prioritas Indonesia dengan pelatihan atau kegiatan inovasi, pendampingan tenaga ahli serta peningkatan upah tenaga kerja.
Pengembangan SDM yang dalam hal ini adalah tenaga kerja merupakan faktor penting dalam mempengaruhi pertumbuhan produksi di sektor industri prioritas yang pada akhirnya berimbas pada peningkatan daya saing sektor industri prioritas Indonesia di kawasan ASEAN.

Upaya peningkatan daya saing yang keempat dapat dilakukan melalui kebijakan yang berhubungan dengan nilai tukar yang dibagi menjadi dua bagian, yaitu dari sisi penjualan dan dari sisi pembelian. Dari sisi penjualan, kenaikan nilai tukar Rupiah terhadap Dollar Amerika Serikat atau yang sering disebut dengan depresiasi Rupiah menyebabkan permintaan terhadap produk-produk yang dihasilkan oleh sektor industri prioritas Indonesia dari kawasan ASEAN meningkat dikarenakan harga dari produk-produk tersebut menjadi lebih murah akibat Rupiah terdepresiasi. Dengan demikian, pada saat Rupiah terdepresiasi, strategi promosi ekspor, misalnya melalui kegiatan pameran internasional dirasa tepat untuk dilakukan guna memperluas akses pasar yang pada akhirnya dapat mendorong peningkatan daya saing.

Sementara itu, dari sisi pembelian, kenaikan nilai tukar Rupiah terhadap Dollar Amerika Serikat dapat menyebabkan peningkatan biaya produksi. Pada saat Rupiah terdepresiasi, secara otomatis harga bahan baku impor menjadi lebih mahal sehingga mendorong meningkatnya biaya produksi dan harga ekspor. Oleh karena itu, strategi pembatasan impor bahan baku guna menjaga lonjakan impor yang melebihi pertumbuhan ekspor perlu dilakukan.

\section{KESIMPULAN DAN SARAN}

\section{Kesimpulan}

Berdasarkan uraian di atas, maka dapat disimpulkan bahwa: 
1. Indonesia memiliki kinerja atau daya saing (komparatif) di sektor industri prioritasnya. Alasannya adalah karena sebagian besar industri prioritasnya yang menjadi andalan Indonesia untuk diunggulkan di pasar ASEAN memiliki performa yang baik. Hal ini terlihat dari hasil analisis RCA, dimana nilai RCA rata-rata tahunannya (2001-2013) yang lebih besar dari satu (RCA $>1)$. Industri-industri prioritas yang berdaya saing tersebut, antara lain industri Makanan dan Minuman, industri Tekstil, industri Pakaian Jadi, industri Kulit dan Barang dari Kulit serta industri Logam Dasar. Sedangkan industri-industri prioritas yang tidak berdaya saing di pasar ASEAN meliputi industri Kimia dan Barang-barang dari Bahan Kimia, industri Mesin dan Perlengkapannya serta industri Furnitur yang memiliki $\mathrm{RCA}<1$.

2. Sementara itu, terkait dengan faktor-faktor yang mempengaruhi daya saing sektor industri prioritas Indonesia, dapat disimpulkan bahwa harga ekspor merupakan faktor yang paling berpengaruh terhadap daya saing sektor industri prioritas Indonesia. Faktor yang berpengaruh lainnya adalah nilai tukar riil Rupiah terhadap Dollar Amerika Serikat dan produktivitas tenaga kerja.

3. Merujuk pada hasil analisis deskriptif kualitatif dan kuantitatif dengan metode RCA dan data panel, terdapat beberapa strategi atau kebijakan yang dapat digunakan dalam upaya peningkatan daya saing sektor industri prioritas Indonesia, antara lain: (1) Mengendalikan ekspor bahan mentah. Pengurangan ekspor bahan mentah yang kemudian dialokasikan untuk bahan baku industri domestik, diharapkan dapat mengurangi ketergantungan terhadap bahan baku impor. Dengan demikian, biaya produksi dapat lebih murah dan pada akhirnya dapat berdampak pada rendahnya harga ekspor. (2) Peningkatan nilai tambah produk melalui kegiatan diversifikasi produk dan meningkatkan kerjasama dengan produsen negara lain di kawasan ASEAN melalui promosi ekspor, sehingga dapat mendukung kegiatan diversifikasi pasar tujuan ekspor ke arah yang lebih prospektif. (3) Meningkatkan produktivitas tenaga kerja melalui pengembangan SDM pelaku industri dengan pelatihan dan pendampingan tenaga ahli serta melalui peningkatan upah tenaga kerja. (4) Memberikan perhatian khusus kepada industri yang dapat menurunkan tekanan pada defisit neraca perdagangan, yaitu industri yang kandungan impornya tinggi, namun masih tetap berdaya saing melalui strategi promosi ekspor dan substitusi impor secara efektif. (5) Kebijakan hilirisasi industri yang berbasis sumber daya alam karena dapat mengurangi risiko saat terjadi fluktuasi harga komoditas dan nilai tukar.

\section{Saran}

Lebih lanjut, terdapat beberapa saran yang dapat diajukan, antara lain:

1. Terkait dengan sektor industri prioritas yang belum berdaya saing di pasar ASEAN, yaitu industri Kimia dan Barang-barang dari Bahan Kimia, industri Mesin dan Perlengkapannya serta industri Furnitur, diperlukan dukungan untuk pengembangan kapasitas kelembagaan ekspor seperti memfasilitasi promosi tetap, peningkatan kemampuan negoisasi dan usaha membangun kepercayaan internasional. Hal-hal tersebut diperlukan karena ketika tarif dihapuskan, maka yang berperan dalam menentukan performa ekspor 
Indonesia adalah daya saing. Khusus untuk industri Furnitur, karena pasar tujuan ekspor utamanya adalah ke negara-negara di luar kawasan ASEAN, maka upaya peningkatan daya saing dengan cara meningkatkan kerjasama dengan produsen negara-negara ASEAN dapat dilakukan sehingga mendukung kegiatan diversifikasi pasar ke kawasan ASEAN untuk produk-produk yang dihasilkan oleh industri Furnitur Indonesia. Upaya ini tentunya dapat terealisasi sepanjang dalam pelaksanaannya, dilakukan secara sinergi dan terintegrasi dengan pengembangan sektor ekonomi lainnya.

2. Indonesia harus terlibat secara aktif dalam perdagangan global, maka alternatif terbaik adalah menyesuaikan arah atau orientasi perdagangan internasional, yakni lebih mengutamakan kerjasama atau hubungan dagang dengan sesama negara ASEAN. Bagi Indonesia, akan sangat baik seandainya memperkuat upaya integrasi ekonomi di antara sesama negara anggota demi menggalang kekuatan, memaksimalkan skala ekonomis, dan juga memperbesar pasar dengan cara mencari pasar-pasar internasional yang potensial.

\section{DAFTAR PUSTAKA}

Anwar MF, Darsono, Agustono. 2012. Analisis Daya Saing Industri Furnitur Rotan Kabupaten Sukoharjo. [Tesis]. Surakarta (ID): Universitas Sebelas Maret.

Arianti RK, Lubis AD. 2011. Analisis Daya Saing dan Kesiapan Indonesia dalam Rangka Integrasi ASEAN: Studi Kasus Automotives, Rubber Based dan Agro Based
Products. Buletin Ilmiah Litbang Perdagangan. 5(1): 1-21. Jakarta (ID): Kementerian Perdagangan.

Aysegul S, Hobijn B. 2006. On Flexibity and Productivity. Meeting Papers 737, Society for Economic Dynamics.

Badan Pusat Statistik. Statistik Industri Besar dan Sedang. [Internet]. [Diunduh Januari 2015]. Tersedia pada: http://www.bps.go.id.

Balassa B. 1961. The Theory of Economic Integration. Homewood: Richard D. Irwin, Inc.

Baltagi BH. 2005. Econometric Analysis of Panel Data. London: John Wiley \& Sons LTD.

Bloch H, McDonal JT. 2000. Import Compatition and Labour Productivity. Melbourne Working Paper, No. 9, Tahun 2000. Melbourne (AUS): University of Melbourne.

Wali A. 2014. Daya Saing Indonesia dalam Menghadapi ASEAN Economic Community (AEC) 2015. [Internet]. [Diakses 2 April 2014]. Tersedia pada:

http://adriwali.blogspot.com/2014/ 04/daya-saing-indonesia-dalam menghadapi asean economic community.html.

Efendi. 2013. Analysis of Indonesia Textile Industry Competitiveness in Regulation Theory Perspective.

Firdaus M. 2011. Aplikasi Ekonomatrika untuk Data Panel dan Time Series. Bogor (ID): IPB Press.

[GAPMMI] Gabungan Pengusaha Makanan dan Minuman Seluruh Indonesia. [Internet]. [Diakses 19 Oktober 2015]. Tersedia pada: http://www.gapmmi.or.id Versi Online: 
http://www.gapmmi.or.id/?pilih=li hat\&id=96.

Idris F. 2007. Kebijakan dan Strategi Pengembangan Industri Nasional, Jakarta (ID): Departemen Perindustrian.

IMD World Competitiveness. 2014. Peringkat Daya Saing Industri Manufaktur Negara-negara ASEAN. [Internet]. [Diunduh 22 Mei 2015]. Tersedia pada: http://www.imd.org/news/2014-W orld-Competitiveness.cfm.

Isftifadah N. 2012. Peluang dan Tantangan Integrasi Ekonomi ASEAN bagi Perekonomian Indonesia. [Tesis]. Surabaya (ID): Universitas Airlangga.

Karakaya E, Ozgen. 2002. Economic Feasibility of Turkey's Economic Integration with the EU: Perspectives from Trade Creation and Trade Diversion.

Kementerian Perdagangan. 2011. Kajian Dampak Kesepakatan

Perdagangan Bebas terhadap Daya Saing Produk Manufaktur Indonesia. Jakarta (ID): Kementerian Perdagangan.

Kementerian Perindustrian. 2013. Pertumbuhan Industri Manufaktur Ditarget 7,14\%. Media Industri No. 01. 2013. Jakarta (ID): Kementerian Perindustrian.

2013. Mengukur Kesiapan Industri Nasional Jelang AEC 2015. Media Industri No. 02. 2013. Jakarta (ID): Kementerian Perindustrian.

2015. Meningkatkan Daya Saing Melalui Hilirisasi Industri. Media Industri No. 01. 2015. Jakarta (ID): Kementerian Perindustrian.
Miftahudin H. 2015 Mei 15. Hadapi MEA, ini 9 Sektor Industri yang Jadi Fokus Kemenperin. Metro News. [Internet]. [Diakses 22 Mei 2015]. Tersedia pada: http://ekonomi.metrotvnews.com/r ead/2015/05/15/126237/hadapi-me a-ini-9-sektor-industri-yang-jadi-fo kus-kemenperin.

Porter ME. 1990. The Competitive Advantage of Nations. Free Press, New York.

Sholeh. 2013. Persiapan Indonesia dalam Menghadapi AEC (ASEAN Economic Community) 2015. Jurnal Ilmu Hubungan Internasional, 1(2): 509-522. Samarinda (ID): Universitas Mulawarman.

Siggel E. 2006. International Competitiveness and Comparative Advantage: A survey and a proposal for measurement. Journal of Industry, Competition and Trade, 6(1): 137-159.

Suarez MDLC. 2001. Trade Creation and Trade Diversion for Mercosur. Disertation. Boston University.

Subhan, Sumarwan U, Daryanto A, Kirbrandoko. 2014. Strategy of Competitiveness of Urea Industry in the International Market and its Implication Toward the Development of Urea Industry in Indonesia. International Journal of Business and Management Reveiew, 2(5): 14-30. United Kingdom (UK): Europan Centre for Research Training and Development.

Sugiyanto. 2004. Peningkatan Daya Saing Ekonomi Indonesia. Jurnal Dinamika Ekonomi dan Bisnis, 1(1): 14-27. 
Sulistiani. 2014. Analisis Komparatif Daya Saing Industri Manufaktur di ASEAN. [Tesis]. Medan (ID): Universitas Sumatera Utara.

Tambunan T, Sitepu R. 2012. Ekspor dan Daya Saing. Policy Paper No. 2, Maret 2012. Tim ACTIVE, Kadin Indonesia dan European Union. Jakarta (ID): Kadin Indonesia.
Tambunan T. 2004. Globalisasi dan Perdagangan Internasional. Bogor (ID): Ghalia Indonesia.

[WITS] World Integrated Trade Solution. [Internet]. [Diunduh April 2015]. Tersedia pada: http://wits.worldbank.org/WITS/W ITS/AdvanceQuery/RawTradeDat a/QueryDefinitionSelection.aspx? Page $=$ RawTradeData\&querytoken $=450968 \&$ selection $=$ Existing. 